\title{
Improved efficiency of dye-sensitized solar cells by doping of strontium aluminate phosphor in $\mathrm{TiO}_{2}$ photoelectrode
}

\author{
SEUng Hwangbo ${ }^{1}$, Jin-TAE KIM ${ }^{2}$ AND KyU-SEOG HWANG ${ }^{3 *}$ \\ ${ }^{1}$ Department of Electronic \& Photonic Engineering, Honam University, 59-1 Seobong-dong, Gwangsan-gu, Gwangju \\ 506-714, Korea \\ ${ }^{2}$ Department of Photonic Engineering, Chosun University, 309 Pilmun-daero, Dong-gu, Gwangju 501-759, Korea \\ ${ }^{3}$ Department of Biomedical Engineering, Nambu University, 864-1 Wolgye-dong, Gwangsan-gu, Gwangju 506-824, Korea
}

$\mathrm{SrAl}_{2} \mathrm{O}_{4}: \mathrm{Eu}^{2+}, \mathrm{Dy}^{3+}$ phosphor was synthesized by chemical solution route to use as a dopant in $\mathrm{TiO}_{2}$ layer employed as a photoelectrode for down conversion of ultraviolet and near-ultraviolet to visible and near-infrared light in a dye-sensitized solar cell. Nano-crystalline structure of the $\mathrm{SrAl}_{2} \mathrm{O}_{4}: \mathrm{Eu}^{2+}, \mathrm{Dy}^{3+}$ powder was confirmed by X-ray diffraction analysis and field emission scanning electron microscopy. Monitored at $520 \mathrm{~nm}, \mathrm{SrAl}_{2} \mathrm{O}_{4}: \mathrm{Eu}^{2+}, \mathrm{Dy}^{3+}$ phosphor showed emission peaks at 460 to $610 \mathrm{~nm}$ due to $4 \mathrm{f}^{6} \rightarrow 4 \mathrm{f}^{7}$ transitions of $\mathrm{Eu}^{2+}$ ions. For the study, $\mathrm{SrAl}_{2} \mathrm{O}_{4}: \mathrm{Eu}^{2+}$, $\mathrm{Dy}^{3+}$ phosphor-doped $\mathrm{TiO}_{2}$ layer was deposited on fluorine-doped tin oxide coated glass by electrostatic spray deposition. The short circuit current, open circuit voltage, fill factor, and conversion efficiency of the cells were measured. Experimental results revealed that the device efficiency for the $\mathrm{SrAl}_{2} \mathrm{O}_{4}: \mathrm{Eu}^{2+}, \mathrm{Dy}^{3+}$ phosphor-doped $\mathrm{TiO}_{2}$ layer increased to $7.20 \%$, whereas that of the pure-TiO $\mathrm{O}_{2}$ photoelectrode was $4.13 \%$.

Keywords: phosphor; down conversion; dye-sensitized solar cell

(C) Wroclaw University of Technology.

\section{Introduction}

Many works have been published on the dyesensitized solar cells (DSSCs) since the first prototype reported by O'Regan et al. [1]. DSSCs are prepared from low-cost materials and they can be significantly less expensive than conventional solidstate solar cells. Although conversion efficiency of the DSSCs $(>13 \%)$ is less than that of the best thin-film cells, its price/performance ratio is high enough to allow them to compete with traditional energy sources based on electrical generation [2]. Generally, the sensitizer of the DSSC contains mainly N3 and N719 dyes, and the DSSC consists of a porous nano-crystalline titania film sensitized by a dye for absorbing incident light [3]. The sensitizers mainly include heteroleptic ruthenium $(\mathrm{Ru})$ complexes that have fairly wide absorption spectra $(\Delta \lambda \approx 350 \mathrm{~nm})$ but low molar extinction coefficients $\left(5,000\right.$ to $\left.20,000 \mathrm{M}^{-1} \cdot \mathrm{cm}^{-1}\right)$ [4].

\footnotetext{
*E-mail: khwang@nambu.ac.kr
}

In an ideal case, the sensitizers should absorb across a broad range of the solar spectrum to yield the greatest number of photons. However, the efficiencies of the DSSCs are lower than those of silicon solar cells. An efficient method for increasing the efficiency is widening the absorption range of the DSSC. A lot of metal compounds dyes have been produced. However, even the best of them (N719, N749, and YD2-o-C8) only absorb visible light in the wavelength range of 400 to $800 \mathrm{~nm}$, and most of the solar ultraviolet and infrared light is not absorbed [3, 4]. A method to increase light harvesting and the efficiency of the solar cells can be the usage of an inorganic-organic composite material having a perovskite structure (e.g. $\mathrm{CH}_{3} \mathrm{NH}_{3} \mathrm{PbI}_{3}$ ) [5] and down-converting phosphor $[6,7]$. Such down converter has the ability to convert higher energy photons, below $450 \mathrm{~nm}$, into low energy photons, above $500 \mathrm{~nm}$.

In this study, $1 \mathrm{~mol} \% \mathrm{Eu}$ and $2 \mathrm{~mol} \%$ Dy-doped strontium aluminate $\left(\mathrm{SrAl}_{2} \mathrm{O}_{4}: \mathrm{Eu}^{2+}\right.$, $\mathrm{Dy}^{3+}$ ) phosphors were prepared by using metal 
carboxylate solution. $\mathrm{SrAl}_{2} \mathrm{O}_{4}: \mathrm{Eu}^{2+}, \mathrm{Dy}^{3+}$ phosphors have a wide ultrafiolet (UV) light absorption band and produce blue to green wavelength, which matches the absorption band of the most typically used dyes $\mathrm{N} 719$ [7]. $\mathrm{SrAl}_{2} \mathrm{O}_{4}: \mathrm{Eu}^{2+}, \mathrm{Dy}^{3+}$ as a luminescence source was introduced into the DSSC to increase its efficiency.

\section{Experimental}

The crystalline nano-sized $\mathrm{SrAl}_{2} \mathrm{O}_{4}: \mathrm{Eu}^{2+}$, $\mathrm{Dy}^{3+}$ phosphors were prepared by chemical solution process using stoichiometric quantities of strontium-naphthenate $\left[\mathrm{Sr}_{2}\left(\mathrm{C}_{11} \mathrm{H}_{7} \mathrm{O}_{2}\right)\right]$, europium (III) 2-ethylhexanoate $\left[\mathrm{Eu}\left(\mathrm{C}_{8} \mathrm{H}_{15} \mathrm{O}_{2}\right)_{3}\right]$, dysprosium 2-ethylhexanoate $\left(\mathrm{DyO}_{6} \mathrm{C}_{24} \mathrm{H}_{45}\right)$ and hydroxyaluminum bis (2-ethylhexanoate) $\left(\mathrm{C}_{16} \mathrm{H}_{31} \mathrm{AlO}_{5}\right)$ and toluene which was used as a solvent. The homogeneous sol was transformed into a yellowish powder by pre-firing at $500{ }^{\circ} \mathrm{C}$ for $4 \mathrm{~h}$, and then the precursor was finally annealed at $1100{ }^{\circ} \mathrm{C}$ for $240 \mathrm{~min}$ in $\mathrm{Ar} / \mathrm{H}_{2} 95 \% / 5 \%$ atmosphere. For phosphor-doped DSSC study, a commercially available $\mathrm{P} 25 \quad \mathrm{TiO}_{2}$ powder was used. The $\mathrm{TiO}_{2}$ powder and 5 wt. $\%$ of $\mathrm{SrAl}_{2} \mathrm{O}_{4}: \mathrm{Eu}^{2+}, \mathrm{Dy}^{3+}$ phosphor were ball milled for $24 \mathrm{~h}$, adding $0.5 \mathrm{wt} \%$ of ethyl cellulose in $100 \mathrm{~mL}$ ethanol. The sol was diluted with ethanol to adjust viscosity.

The precursor was coated on a fluorine doped tin oxide coated glass (FTO) using an electrostatic spray deposition (ESD). The ESD has been commonly used to synthesize homogeneous oxide coatings. The working principles of the ESD have been described by Kim et al. [8]. Briefly, to obtain a stable cone-jet mode of electrostatic atomization, high voltage $(20 \mathrm{kV})$ was applied between the needle tip and the electrode by using high DC power supply. FTO substrates on the ground electrode were heated at $80{ }^{\circ} \mathrm{C}$ for $60 \mathrm{~min}$ to vaporize the organic compound. The flow rate of precursor solution containing $\mathrm{SrAl}_{2} \mathrm{O}_{4}: \mathrm{Eu}^{2+}$, $\mathrm{Dy}^{3+}$-doped $\mathrm{TiO}_{2}$ was kept at $0.3 \mathrm{~mL} / 60 \mathrm{~min}$. The as-deposited film was heattreated at $550{ }^{\circ} \mathrm{C}$ for $30 \mathrm{~min}$ in air. The annealed film was immersed in ethanol solution containing $0.0005 \mathrm{M} \mathrm{N} 719$ dye at $40{ }^{\circ} \mathrm{C}$ for $360 \mathrm{~min}$. The counter electrode was prepared by dip-coating a
FTO glass with $\mathrm{H}_{2} \mathrm{PtCl}_{6}$ solution $(2 \mathrm{mg} \mathrm{Pt} / 1 \mathrm{~mL}$ ethanol), followed by heating at $400{ }^{\circ} \mathrm{C}$ for $30 \mathrm{~min}$.

The crystallinity and morphology of the samples were examined by X-ray diffraction (XRD, D-Max 1200, Rigaku, Japan) $\theta$ to $2 \theta$ scan using a $\mathrm{CuK} \alpha(\lambda=1.54056 \AA)$ radiation and field emission scanning electron microscope (FE-SEM, S-4700, Hitachi, Japan). Photoluminescence (PL) spectra at room temperature were obtained using a fluorescent spectrophotometer (F4500, Hitachi, Japan) equipped with a Xenon lamp source. The UV-Vis absorption spectra of the samples were obtained by using a UV-Vis spectrophotometer (Cary 100, Varian Inc., Australia) attached to an internal diffuse reflectance accessory.

The electrolyte solution consisted of 1-butyl-3-methylimidazolium iodide, iodine, 4-tert-butylpyridine, and guanidinium thiocyanate in acetonitrile/valeronitrile at 85:15 volume ratio. The electrolyte was injected into the sealed cells via predrilled holes on the counter electrode, and the injection holes were hot sealed by a piece of thin cover glass with a hot-melt film underneath as the adhesive. The I-V characteristics of DSSCs were measured under 1 sun conditions $\left(100 \mathrm{~mW} / \mathrm{cm}^{2}\right)$ using a solar simulator (Oriel Instruments, U.S.A.) equipped with a $300 \mathrm{~W}$ Xenon lamp and a Keithley (Model 2400) source meter, after calibrating with a silicon reference cell. The cell was covered with an aperture mask, while measuring photocurrent and voltage to avoid overestimation of the I-V characteristics.

\section{Results and discussion}

Fig. 1a shows a typical XRD pattern of $\mathrm{SrAl}_{2} \mathrm{O}_{4}: \mathrm{Eu}^{2+}, \mathrm{Dy}^{3+}$ phosphor annealed at $1100{ }^{\circ} \mathrm{C}$ for $240 \mathrm{~min}$ in $\mathrm{Ar} / \mathrm{H}_{2} 95 \% / 5 \%$ atmosphere. It can be seen that the monoclinic $\mathrm{SrAl}_{2} \mathrm{O}_{4}$ phase pattern is characterized by three peaks around $2 \theta=28$ to $29^{\circ}$ (JCPDS No. 34-0379), and weak peaks at 23.6, 27.8, 30.4 and $34.1^{\circ}$ related to $\mathrm{Sr}_{4} \mathrm{Al}_{14} \mathrm{O}_{25}$ (JCPDS No. 52-1876) as a secondary phase. $\mathrm{Sr}^{2+}$ ions are positioned in the cavities of the framework of corner-sharing $\mathrm{AlO}_{4}^{5-}$ tetrahedra. Oxygen is shared with two 
aluminum ions so that each tetrahedron has one net negative charge. The charge balance is disturbed by $\mathrm{Sr}^{2+}$ ions which occupy interstitial locations within the tetrahedral framework. It is commonly considered that $\mathrm{Eu}^{2+}$ and $\mathrm{Dy}^{3+}$ ions enter into the $\mathrm{Sr}$ ion sites in the $\mathrm{SrAl}_{2} \mathrm{O}_{4}: \mathrm{Eu}^{2+}, \mathrm{Dy}^{3+}$ host. Since the radii of $\mathrm{Eu}^{2+}(0.130 \mathrm{~nm})$ and $\mathrm{Dy}^{3+}$ $(0.117 \mathrm{~nm})$ ions, are approximately equal to that of the $\mathrm{Sr}^{2+}$ ion $(0.127 \mathrm{~nm})$, their replacement does not cause a noteworthy distortion of the lattice parameters [9]. Fig. 1b shows the XRD pattern for a pure- $\mathrm{TiO}_{2}$ sample. The diffraction peaks at $25.3^{\circ}, 37.9^{\circ}, 48.1^{\circ}$, and $53.9^{\circ}$ are from the (101), (004), (200), and (105) reflection planes of anatase phase, and the peaks at $27.5^{\circ}$ and $36.2^{\circ}$ are from the (110) and (101) reflection planes of rutile phase, respectively. This suggests that the P25 is composed of a mixed phase of anatase and rutile. The microstructural morphology of the

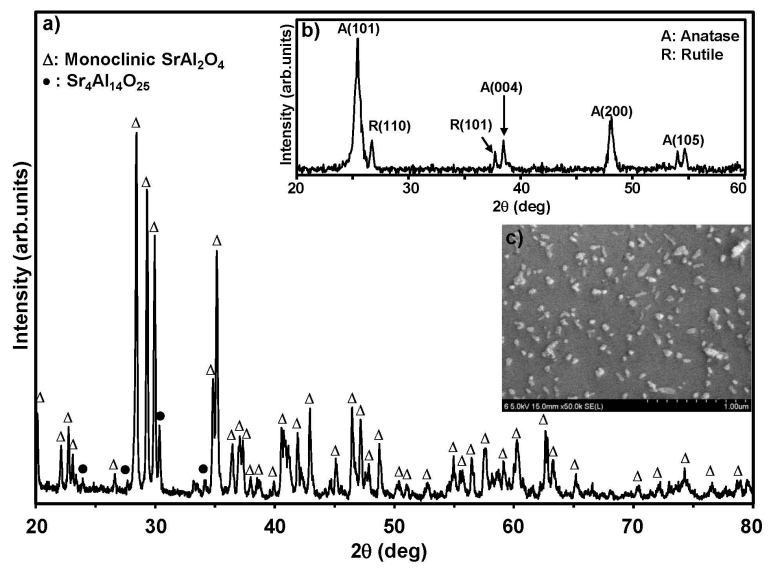

Fig. 1. XRD patterns of $\mathrm{SrAl}_{2} \mathrm{O}_{4}: \mathrm{Eu}^{2+}, \mathrm{Dy}^{3+}$ phosphor after annealing at $1100{ }^{\circ} \mathrm{C}$ for $240 \mathrm{~min}$ in $\mathrm{Ar}$ $-5 \% \mathrm{H}_{2}$ gas (a), and pure $\mathrm{TO}_{2}$ (b) FE-SEM image of the phosphor (c).

$\mathrm{SrAl}_{2} \mathrm{O}_{4}: \mathrm{Eu}^{2+}, \mathrm{Dy}^{3+}$ phosphor after annealing at $1100{ }^{\circ} \mathrm{C}$ for $240 \mathrm{~min}$ is shown in Fig. 1c. Normally, the particle size of $\mathrm{SrAl}_{2} \mathrm{O}_{4}: \mathrm{Eu}^{2+}, \mathrm{Dy}^{3+}$ phosphor prepared by the solid-state reaction is about several micrometers, much larger than those of chemical solution-derived powders. The micrograph shows sharp distributions of particles with an average particle size below $100 \mathrm{~nm}$. The morphology is apparently different from the micrometer-scale particle and/or agglomerations of $\mathrm{SrAl}_{2} \mathrm{O}_{4}$ resulting from solid-state reaction method, indicating that organic components in starting materials can efficiently prevent the formation of larger agglomerations [10].
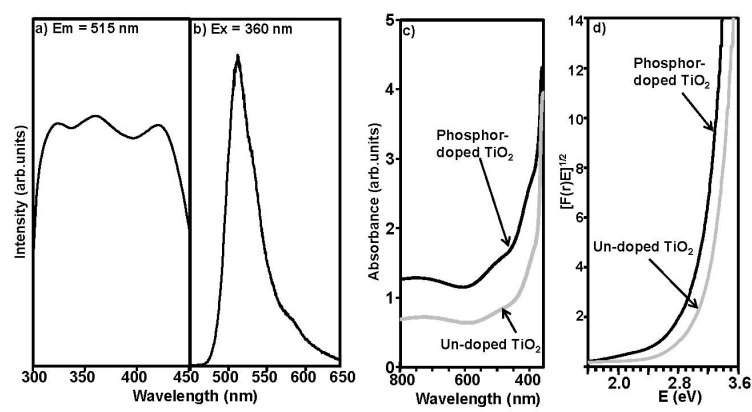

Fig. 2. Excitation (a), emission (b), absorption (c) spectra, and the plot of the transformed KubelkaMunk function vs. photon energy (d) for $\mathrm{SrAl}_{2} \mathrm{O}_{4}: \mathrm{Eu}^{2+}, \mathrm{Dy}^{3+}$ phosphor after annealing at $1100{ }^{\circ} \mathrm{C}$ for $240 \mathrm{~min}$ in $\mathrm{Ar}-5 \% \mathrm{H}_{2}$ gas.

Fig. 2a shows an excitation spectrum of $\mathrm{SrAl}_{2} \mathrm{O}_{4}: \mathrm{Eu}^{2+}, \mathrm{Dy}^{3+}$ phosphor annealed at $1100{ }^{\circ} \mathrm{C}$, monitored from $300 \mathrm{~nm}$ and $500 \mathrm{~nm}$. A wide-ranging band with a maximum at around $360 \mathrm{~nm}$ is observed. The excitation spectrum was obtained by monitoring the emission of the $\mathrm{Eu}^{2+}$ $4 f \rightarrow 5 d$ transitions, and the peak at about $520 \mathrm{~nm}$ resulting in a green emission [11]. Fig. 2b shows the emission spectrum of the $\mathrm{SrAl}_{2} \mathrm{O}_{4}: \mathrm{Eu}^{2+}, \mathrm{Dy}^{3+}$ phosphor monitored for $360 \mathrm{~nm}$ excitation. A broad emission peak is observed at around $515 \mathrm{~nm}$, revealing the characteristic emission of $\mathrm{Eu}^{2+}$ activators $\left(4 f^{6} 5 d^{1} \rightarrow 4 f^{7}\right)$. The slight blue shift in the emission band from $520 \mathrm{~nm}$ to $515 \mathrm{~nm}$, similar to that of the phosphors obtained from solid-state reaction, may be attributed to the changes in the crystal field around $\mathrm{Eu}^{2+}$ arising from the nanosized particles. Zhang et al. [12] reported that the particles with nanometer size make the surface energy increase, which causes variation of the crystal field around the local environment of $\mathrm{Eu}^{2+}$. Since the excited $4 \mathrm{f}^{6} 5 \mathrm{~d}^{1}$ configuration of $\mathrm{Eu}^{2+}$ ion is greatly sensitive to the lattice environment and $5 \mathrm{~d}$ electrons can be strongly coupled with the lattice, the mixed states of $4 \mathrm{f}$ and $5 \mathrm{~d}$ are split by the crystal field, which may lead to the shift of the emission 
peak toward shorter wavelength. Fig. $2 \mathrm{c}$ shows the absorption spectra of the pure- $\mathrm{TiO}_{2}$ photoelectrode and the $\mathrm{TiO}_{2}$ photoelectrode doped with 5 wt.\% of $\mathrm{SrAl}_{2} \mathrm{O}_{4}: \mathrm{Eu}^{2+}, \mathrm{Dy}^{3+}$ phosphor. A comparison of the spectra indicates that phosphor-doped $\mathrm{TiO}_{2}$ can improve light absorption. The absorption spectra display that the pure- $\mathrm{TiO}_{2}$ coating has a lower absorption ability than $\mathrm{SrAl}_{2} \mathrm{O}_{4}: \mathrm{Eu}^{2+}$, $\mathrm{Dy}^{3+}$ phosphor-doped $\mathrm{TiO}_{2}$ coating, specifically for the wavelength range between 350 to $800 \mathrm{~nm}$. These spectra cover a UV-Vis-IR region. Therefore, the doping of $\mathrm{SrAl}_{2} \mathrm{O}_{4}: \mathrm{Eu}^{2+}, \mathrm{Dy}^{3+}$ phosphor was found to decrease the light loss and increase photon energy. The energy band gap $\left(E_{g}\right)$ of the samples was calculated from the plots of Kubelka-Munk function vs. the energy of exciting light [13]. From Fig. 2d, the $\mathrm{E}_{\mathrm{g}}$ of pure- $\mathrm{TiO}_{2}$ and phosphor-doped $\mathrm{TiO}_{2}$ was obtained to be $3.2 \mathrm{eV}$ and $3.02 \mathrm{eV}$, respectively. Thus, the phosphor doping of $\mathrm{TiO}_{2}$ induced a shift of the absorption edge slightly towards the visible spectral range.
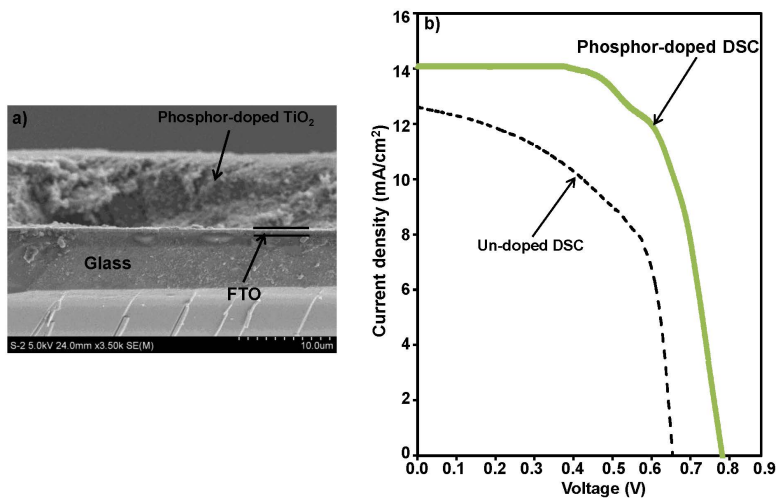

Fig. 3. Cross-sectional FE-SEM image of $\mathrm{SrAl}_{2} \mathrm{O}_{4}$ : $\mathrm{Eu}^{2+}, \mathrm{Dy}^{3+}$ phosphor-doped $\mathrm{TiO}_{2}$ layer (a), and I-V curves of DSSCs with and without nanophosphor in $\mathrm{TiO}_{2}$ photoelectrode (b).

In order to evaluate the effect of $\mathrm{SrAl}_{2} \mathrm{O}_{4}: \mathrm{Eu}^{2+}$, $\mathrm{Dy}^{3+}$ phosphor in $\mathrm{TiO}_{2}$ electrode on the efficiency of DSSC, the working electrode was prepared by ESD using a precursor solution containing 5 wt.\% of $\mathrm{SrAl}_{2} \mathrm{O}_{4}: \mathrm{Eu}^{2+}, \mathrm{Dy}^{3+}$ phosphor in $\mathrm{TiO}_{2}$ powder. Fig. 3a displays a cross-sectional image of the $\mathrm{SrAl}_{2} \mathrm{O}_{4}: \mathrm{Eu}^{2+}, \mathrm{Dy}^{3+}$ doped- $\mathrm{TiO}_{2}$ layer on a FTO substrate. The thickness of the film is uniform at $\sim 8 \mu \mathrm{m}$, as determined by the cross-sectional image. The film does not contain any aggregations of $\mathrm{TiO}_{2}$ particles, which are dispersed homogeneously.

Fig. $3 b$ shows the photovoltaic I-V characteristics of the pure- $\mathrm{TiO}_{2}$-based DSSC and $\mathrm{SrAl}_{2} \mathrm{O}_{4}: \mathrm{Eu}^{2+}, \mathrm{Dy}^{3+}$ phosphor-doped $\mathrm{TiO}_{2}$-based DSSC. The light-to-electric-energy conversion efficiency $(\eta)$ of the DSSC systems with the pure$\mathrm{TiO}_{2}$ photoelectrode as well as $\mathrm{SrAl}_{2} \mathrm{O}_{4}: \mathrm{Eu}^{2+}$, $\mathrm{Dy}^{3+}$ phosphor-doped $\mathrm{TiO}_{2}$ photoelectrode were calculated using equation 1 , with the values of short-circuit photocurrent density $\left(\mathrm{J}_{s c}, \mathrm{~mA} / \mathrm{cm}^{2}\right)$, the open circuit voltage $\left(\mathrm{V}_{o c}, \mathrm{~V}\right)$, the fill factor $(\mathrm{FF})$ taken from the I-V characteristics:

$$
\eta(\%)=J_{s c} \times V_{o c} \times \frac{F F}{I}
$$

where I is the intensity of the incident light. The FF is defined by equation 2 :

$$
F F=\frac{J_{\max }\left(V_{\max }\right)}{J_{s c}\left(V_{o c}\right)}
$$

where $\mathrm{J}_{\max }$ and $\mathrm{V}_{\max }$ are the photocurrent density and the photovoltage, respectively, in the $\mathrm{I}-\mathrm{V}$ curve at the point of maximum power output. Fig. $3 b$ and Table 1 show that the DSSC with undoped $\mathrm{TiO}_{2}$ have the following photovolatic parameters: $\mathrm{J}_{s c}=12.3 \mathrm{~mA} / \mathrm{cm}^{2}$, $\mathrm{V}_{o c}=0.65 \mathrm{~V}, \mathrm{~J}_{\max }=8.6 \mathrm{~mA} / \mathrm{cm}^{2}, \mathrm{~V}_{\max }=0.48 \mathrm{~V}$, $\mathrm{FF}=51.6 \%$ and $\eta=4.13 \%$. The DSSC containing the $\mathrm{SrAl}_{2} \mathrm{O}_{4}: \mathrm{Eu}^{2+}, \mathrm{Dy}^{3+}$ phosphor as a dopant has the improved photovoltaic parameters: $\mathrm{J}_{s c}=14.1 \mathrm{~mA} / \mathrm{cm}^{2}, \mathrm{~V}_{o c}=0.78 \mathrm{~V}$, $\mathrm{J}_{\max }=12 \mathrm{~mA} / \mathrm{cm}^{2}, \mathrm{~V}_{\max }=0.6 \mathrm{~V}, \mathrm{FF}=65.7 \%$ and $\eta=7.20 \%$. The pure- $\mathrm{TiO}_{2}$ device efficiency of $4.13 \%$, is improved to $7.20 \%$ for the $\mathrm{SrAl}_{2} \mathrm{O}_{4}: \mathrm{Eu}^{2+}, \mathrm{Dy}^{3+}$ phosphor-doped-TiO 2 layer. When the phosphor powder was inserted, the number of photons increased, hence, the possibility of photon and dye molecule interactions increased, whereas the DSSC with the pure- $\mathrm{TiO}_{2}$ layer had lower $\mathrm{J}_{s c}$ and $\mathrm{V}_{o c}$ because of lower number of excitations [6]. The improvement of the photovoltaic performances shows that the $\mathrm{SrAl}_{2} \mathrm{O}_{4}: \mathrm{Eu}^{2+}, \mathrm{Dy}^{3+}$ phosphor transforms UV to Vis and near-IR light which the $\mathrm{N}-719$ dye can absorb effectively, increasing the harvested sunlight and improving the efficiency of the DSSC. 
Table 1. Performance of DSSCs based on different photoelectrodes.

\begin{tabular}{ccccccc}
\hline Photoelectrode & $\begin{array}{c}\mathrm{J}_{s c} \\
\left(\mathrm{~mA} / \mathrm{cm}^{2}\right)\end{array}$ & $\begin{array}{c}\mathrm{V}_{o c} \\
(\mathrm{~V})\end{array}$ & $\begin{array}{c}\mathrm{J}_{\max } \\
\left(\mathrm{mA} / \mathrm{cm}^{2}\right)\end{array}$ & $\begin{array}{c}\mathrm{V}_{\max } \\
(\mathrm{V})\end{array}$ & $\begin{array}{c}\mathrm{FF} \\
(\%)\end{array}$ & $\begin{array}{c}\eta \\
(\%)\end{array}$ \\
\hline \hline Undoped $\mathrm{TiO}_{2}$ & 12.3 & 0.65 & 8.6 & 0.48 & 51.6 & 4.13 \\
Phosphor-doped $\mathrm{TiO}_{2}$ & 14.1 & 0.78 & 12 & 0.6 & 65.7 & 7.20 \\
\hline
\end{tabular}

\section{Conclusions}

Down-conversion $\mathrm{SrAl}_{2} \mathrm{O}_{4}$ phosphor was fabricated by using chemical solution method to improve the power transformation efficiency of DSSCs by means of solar spectral transformation. 5 wt.\% of $\mathrm{SrAl}_{2} \mathrm{O}_{4}: \mathrm{Eu}^{2+}, \mathrm{Dy}^{3+}$ phosphor-doped$\mathrm{TiO}_{2}$ photoelectrode on FTO substrate was prepared by the ESD process. The pure- $\mathrm{TiO}_{2}$ device efficiency of $4.13 \%$, was increased to $7.20 \%$ for the $\mathrm{SrAl}_{2} \mathrm{O}_{4}: \mathrm{Eu}^{2+}, \mathrm{Dy}^{3+}$ phosphor-doped- $\mathrm{TiO}_{2}$ layer. The photovoltaic performances show that the $\mathrm{SrAl}_{2} \mathrm{O}_{4}: \mathrm{Eu}^{2+}, \mathrm{Dy}^{3+}$ phosphor converts UV to Vis and near-IR light which the N719 dye can absorb effectively, increasing the harvested sunlight and improving the efficiency of the DSSC.

\section{Acknowledgements}

This work was supported in part by research funds from Nambu University, 2013.

\section{References}

[1] O’Regan B., GrätZEL M., Nature, 353 (1991), 737.

[2] He W., Timur A.S.H., Kim H.K., Hwang Y.H., IOP Conf-Mater. Sci. Eng., 54 (2014), 012025.
[3] GRÄTZEL M., Nature, 414 (2001), 338.

[4] Hagfeldt A., Boschloo G., Sun L., Kloo L., Pettersson H., Chem. Rev., 110 (2010), 6595.

[5] GRÄTZEL M., Nat. Mater., 13 (2014), 838.

[6] Hong C., Ko H., HaN E., Yun J., PARK K., Nanoscale Res. Lett., 8 (2013), 219.

[7] He W., Timur A.S.H., Kim H.K., Hwang Y.H., J. Phys. Chem. C, 117 (2013), 17894.

[8] KIm S.G., KIM J.Y., KIM H.J., Thin Solid Films, 376 (2000), 110.

[9] Haranath D., Shanker V., Chander H., Sharma P., J. Phys. D Appl. Phys., 36 (2003), 2244.

[10] Han C.H., LeE H.S., HAN S.D., B. Korean Chem. Soc., 29 (2008), 1495.

[11] Escribano P., Marchal M., Sanjuan M.L., Alonso-Gutierrez P., Julian B., Cordoncillo E., J. Solid State Chem., 178 (2005), 1978.

[12] Zhang R., HAn G., Zhang L., Yang B., Mater. Chem. Phys., 113 (2009), 255.

[13] Hreniak A., Sikora A., Iwan A., Int. J. Mater. Chem., 4 (2014), 15. 